\title{
Nanotechnology in veterinary medicine: a review
}

\author{
Lara Baccarin Ianiski ${ }^{1,2}$ (i) Fernando de Souza Rodrigues ${ }^{3}$ (i) Paula Cristina Stibbe Pa $^{1,2}$ \\ Carla Weiblen $^{3}$ (i) Daniela Isabel Brayer Pereira ${ }^{4}$ (i) Janio Morais Santurio ${ }^{2}$ (i) \\ Cristiane de Bona da Silva ${ }^{1}$ Luis Antônio Sangioni ${ }^{3}$ Fernanda Silveira Flores Vogel $^{3}$ (D) \\ Mateus Matiuzzi da $\operatorname{Costa}^{5}$ (i) Valéria Dutra ${ }^{6}$ (i) Luciano Nakazato $^{6}$ (i) Sônia de Avila Botton $^{1,3^{*}}$ (i)
}

${ }^{1}$ Programa de Pós-graduação em Ciências Farmacêuticas (PPGCF), Centro de Ciências da Saúde (CCS), Universidade Federal de Santa Maria (UFSM), Santa Maria, RS, Brasil.

${ }^{2}$ Departamento de Microbiologia e Parasitologia, Laboratório de Pesquisas Micológicas, Centro de Ciências da Saúde (CCS), Universidade Federal de Santa Maria (UFSM), Santa Maria, RS, Brasil.

${ }^{3}$ Programa de Pós-graduação em Medicina Veterinária (PPGMV), Departamento de Medicina Veterinária Preventiva (DMVP), Centro de Ciências Rurais, Universidade Federal de Santa Maria (UFSM), 97105-900, Santa Maria, RS, Brasil. E-mail: sabott20@gmail.com. "Corresponding author. ${ }^{4}$ Departamento de Microbiologia e Parasitologia, Instituto de Biologia, Universidade Federal de Pelotas (UFPel), Pelotas, RS, Brasil. ${ }^{5}$ Colegiado de Zootecnia, Universidade Federal do Vale do São Francisco (UNIVASF), Petrolina, PE, Brasil. ${ }^{6}$ Departamento de Medicina Veterinária Preventiva, Universidade Federal do Mato Grosso (UFMT), Cuiabá, MT, Brasil.

ABSTRACT: The purpose of this review was to address the applicability of nanotechnology in veterinary medicine, with an emphasis on research in Brazil from 2013 to 2020. Firstly, we introduced to the general aspects of applicability of nanotechnology in veterinary medicine, and lately we pointed the research involving nanoscience performed in Brazil, in the studied period. Nanotechnology is the field of science that has the capacity to organize matter in nanoscale structures (1 to $100 \mathrm{~nm}$ ), enabling innovations in different areas including biotechnology, agriculture, disease diagnosis, food and clothing industry, electronics, and pharmacological therapies. In veterinary medicine, several studies are being carried out in the world, mainly in the areas that involve search of new treatment options and the development of immunotherapy, as well as in the diagnosis of diseases. In Brazil, it is clear that the use of nanotechnology in veterinary medicine is still incipient, but it can be considered a growing area. In addition, several points have to be reflected and researched, including some adverse effects and implications to validate the safe use of nanotechnology in veterinary medicine. Therefore, this review highlighted the nanotechnology as a promise alternative in the current context of Brazilian technological innovation involving animal health, as well as a possible diagnostic tool and highlighting its potential therapeutic use in disease control in veterinary medicine. Regarding future perspectives, we believed that greater investment in science and technology could contribute to the advancement and strengthening of nanotechnology in Brazil.

Key words: nanoscience, technological innovation, animal health, diagnostic, treatment.

Nanotecnologia em medicina veterinária: uma revisão

RESUMO: O objetivo desta revisão foi abordar a aplicabilidade da nanotecnologia na medicina veterinária, com ênfase nas pesquisas no Brasil de 2013 a 2020. Primeiramente, apresentam-se os aspectos gerais da aplicabilidade da nanotecnologia em medicina veterinária e, posteriormente, apontam-se as pesquisas envolvendo nanociência realizadas no Brasil, no periodo estudado. A nanotecnologia é o campo da ciência capaz de organizar a matéria em estruturas de nanoescala (1 a $100 \mathrm{~nm}$ ), permitindo inovações em diferentes áreas, incluindo biotecnologia, agricultura, diagnóstico de doenças, indústria de alimentos e vestuário, eletrônica e terapias farmacológicas. Na medicina veterinária, diversos estudos estão sendo realizados no mundo, principalmente nas áreas que envolvem a busca de novas opções de tratamento e o desenvolvimento de imunoterapia, bem como no diagnóstico de doenças. No Brasil, está claro que o uso da nanotecnologia na medicina veterinária ainda é incipiente, mas pode ser considerada uma área em crescimento. Além disso, vários pontos devem ser refletidos e pesquisados, incluindo alguns efeitos adversos e implicações para validar o uso seguro da nanotecnologia na medicina veterinária. Nesta revisão, destaca-se a nanotecnologia como uma alternativa promissora no atual contexto de inovação tecnológica brasileira, envolvendo saúde animal, o diagnóstico e o potencial uso terapêutico no controle de doenças em medicina veterinária. Em relação às perspectivas futuras, acredita-se que maiores investimentos em ciência e tecnologia são fatores fundamentais a contribuir para o avanço e fortalecimento da nanotecnologia no Brasil.

Palavras-chave: nanociência, inovação tecnológica, saúde animal, diagnóstico, tratamento.

\section{INTRODUCTION}

Nanotechnology refers to the manipulation of the structure of materials, substances, or elements at the nanometer scale, producing structures between $1.0 \mathrm{~nm}$ and $100 \mathrm{~nm}$ (ROCO, 2011; PELAZ et al., 2017). In 1959, Richard Feynman first mentioned the concept of nanotechnology in the lecture Plenty of 
Room at the Bottom in Nobel Prize, proposing that mounting a material atom by atom would never be possible (FEYNMAN, 1960). With the discovery of fullerenes (KROTO et al., 1985) and the synthesis of carbon nanotubes (IIJIMA, 1991), nanoscience and nanotechnology - once viewed as fiction - was considered a viable technology (FERREIRA et al., 2009). In 1991, a processing method involving the molecular manipulation of atoms was proposed (FERREIRA et al., 2009). Later, different areas of activity contributed to nanotechnology. These included, among others, chemistry, biology, molecular physics, material science, computer science, and electrical and mechanical engineering (ROCO, 2011).

The increased interest in the applications of nanotechnology in medicine has led to the emergence of a new field called nanomedicine (PROW et al., 2004; FREITAS JR., 2005; PELAZ et al., 2017).

Research on nanoparticles is promising in the areas of disease diagnosis, control, and treatment. In addition, it is promising in the development of strategies for improving animal fertility and reducing contaminants in industry (VON SAMSONHIMMELSTJERNA et al., 2005; SMITH et al., 2013; ALI et al., 2014; CHAO et al., 2016; KING et al., 2018; SHAKIR et al., 2018; FEUGANG et al., 2019). Nanotechnology has been identified as a high impact technology in the $21^{\text {st }}$ century, particularly in the livestock industry (FEUGANG et al., 2019).

Scientifically validated nanoparticle products have been incorporated into marketable products for veterinary medicine (UNDERWOOD et al., 2012). This highlights the growth of research involving nanotechnology as a science applicable to veterinary medicine.

The aim of this narrative review is to address the applicability of nanotechnology in veterinary medicine with emphasis on research in Brazil from 2013 to 2020 . This narrative review has the following structure: the reader is first introduced to the general aspects of applicability of nanotechnology in veterinary medicine, while later describing the research involving nanoscience performed in Brazil in the mentioned period.

\section{Therapeutic applications}

Drug delivery systems using nanoparticles are their most widespread applications (PROW et al., 2005). The following advantages were obtained using this technology; assistance in the delivery of unstable and insoluble drugs, maintenance of active principle concentration at the expected site of action, and low systemic toxicity and reduced clearance compared to that of the original drug (SAHOO et al., 2003; BAKKER-WOUDENBERG et al., 2005; FAHMY et al., 2005; PARVEEN et al., 2012). Thus, nanoparticle formulations require lower therapeutic doses than conventional drugs. This feature is very important in veterinary medicine as it allows lower doses of drugs and favors the reduction in residual levels of pharmaceuticals, particularly antimicrobials in carcasses and other animal products, as well as reduction in the cost of treatment (UNDERWOOD et al., 2012).

Various drug delivery systems with nanoparticles have been developed. These include antineoplastic drugs (HOFHEINZ et al., 2005), antimicrobials (CORDEIRO et al., 2000), analgesics (ROSE et al., 2005), and anti-inflammatory drugs (METSELAAR et al., 2003). In veterinary medicine, nanoparticles of various substances have been tested for antibacterial (OLIVEIRA et al., 2013; SAGAVE et al., 2015; JAGUEZESKI et al., 2019; ACOSTA et al., 2020), antiviral (GREENWOOD et al., 2008; ZHAO et al., 2016; ZHAO et al., 2018), anthelmintic (KHAN et al., 2015; TOMAR et al., 2017; REHMAN et al., 2019), antiprotozoal (KROUBI et al., 2010; HASSAN et al., 2019), antifungal (BANSOD et al., 2015), antioomycetes (VALENTE et al., 2016; VALENTE et al., 2019; VALENTE et al., 2020), anti-algae (JAGIELSKI et al, 2018; ELY et al., 2020), and antineoplastic (ROCHA et al., 2019) activities.

The passage of nanoparticles to specific locations can occur passively or actively through vectorization. In active vectorization, the mechanism of action is due to the coupling of a targeting portion. These include specific binders for molecular recognition, monoclonal antibodies, transferrin, peptides, or portions of sugars that lead drugs to the site of action (Figure 1-A). The passive form is supported by the intrinsic properties of the nanostructured molecule and occurs through the retention and increased permeability effect. This is based on the ability of the nanoparticles to spill blood vessels to other tissues, resulting in accumulation at sites of increased vascular permeability (tumors, infections, and inflammatory areas) (Figure 1-B) (ISHIHARA et al., 2010; MAEDA, 2010; PARVEEN et al., 2012). The combination of passive vectorization with active vectorization can potentiate the nanocarrier effect thereby increasing the effectiveness of treatment (CHEN et al., 2010; DANHIER et al., 2010; LEE et al., 2012).

COUVREUR (1993) and LIU et al. (2007) reported that the standard mechanisms involved in the release of drugs include enzymatic degradation or disintegration and fusion with the cell membrane surface, releasing the contents into 


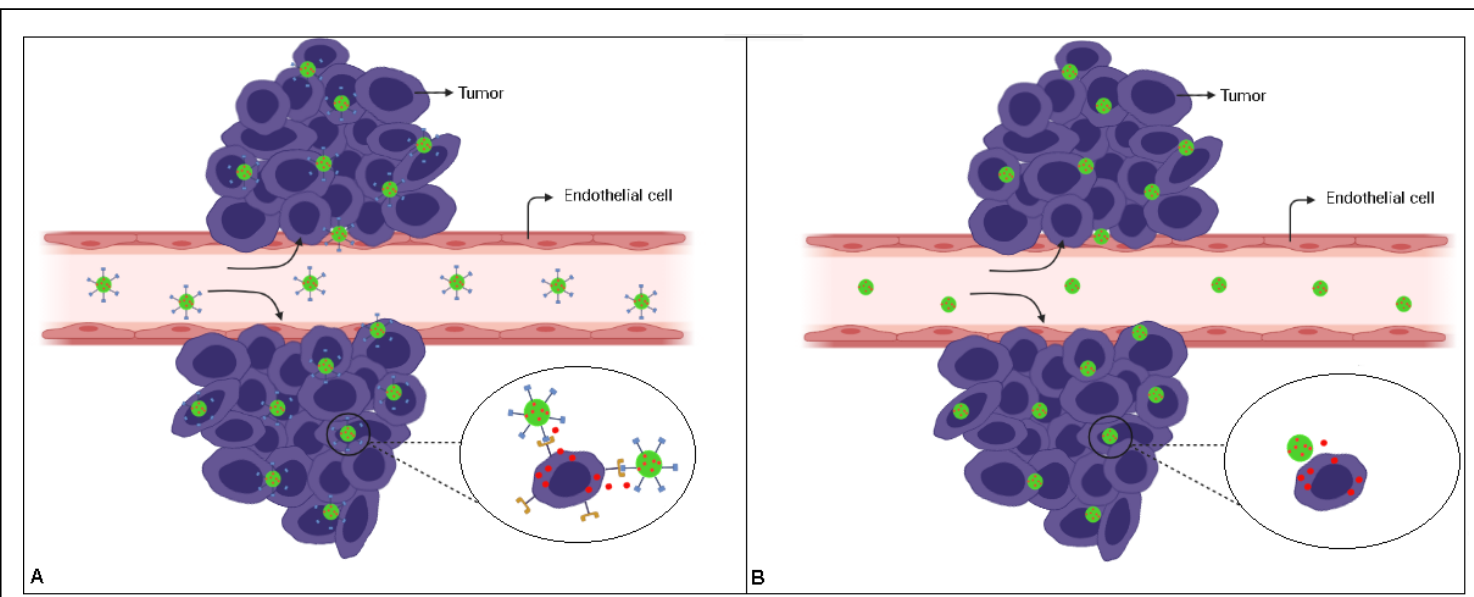

Figure 1 - Schematic representation of the action of nanoparticles (green spheres), e.g., in tumor cells. (A) Active vectoring: the mechanism of action is due to the modification of the surface of the nanoparticles with molecules that can be recognized by specific ligands for molecular recognition, monoclonal antibodies, transferrin, peptides or portions of sugars that lead the drugs to the site of action. (B) Passive vectoring: this mechanism is supported by the intrinsic properties of nanoparticles, resulting in accumulation in tumor regions, as well as infections and inflammatory areas, due to the greater vascular permeability in these locations.

the cell and/or endocytosis. These mechanisms can be triggered by external factors such as changes in temperature, $\mathrm{pH}$ and magnetic field. To avoid such influences, nanostructured systems (polymeric or lipid nanoparticles, nanoemulsions, and liposomes) appeared to be a great option with several advantages. These include the improvement in efficacy and bioavailability of drugs, reduction of side effects, increased stability, and reduced drug delivery rate (SCHAFFAZICK et al., 2003; PADMAVATHY et al., 2008; MISHRA et al., 2011).

The term nanoparticles includes nanocapsules and nanospheres, which differ in composition and structural organization. Nanocapsules are formed by a polymeric shell disposed around an oily core; the drug may be dissolved in the core and/or adsorbed to the polymeric wall. Moreover, nanospheres, which have no oil in their composition, are formed by a polymeric matrix in which the drug can be entrapped or adsorbed (ALLEMANN et al., 1993).

Nanoemulsions are droplets dispersed in the size range of nanoparticles, which provide stability for preventing sedimentation or creaming (SOLANS, 2005). These characteristics allow some water-soluble substances to remain permanently stable in the aqueous phase (VANDAMME et al., 2010). The formulations are suitable for therapeutic use due to their inability to cause cell damage and possible application to the skin and/or mucous membranes. Nanoemulsion formulations may also be used to transport insoluble drugs in aqueous media, carry antigens to generate mucosal immunity, and in anticancer therapies (THAKUR et al., 2012).

Liposomes are microscopic vesicles composed of one or more concentric lipid bilayers separated by an aqueous medium. These structures have the ability to encapsulate hydrophilic and/ or lipophilic substances where the first stand in the aqueous compartment and the lipophilic substance is inserted or adsorbed into the membrane. Liposomes are biodegradable, biocompatible, and non-immunogenic and are highly versatile for research, therapeutic, and analytical applications (EDWARDS et al., 2006).

\section{Industry}

Nanomaterials have been used in different industries, offering potential applications in providing solutions through green chemistry approaches for advancing food security (KING et al., 2018). Titanium dioxide nanoparticles are the most commonly used metal oxide nanoparticles in various industrial and commercial products, including food (WEIR et al., 2012). Silver nanoparticles and nanocomposites are the most widely used antimicrobial nanomaterials in the food industry due to their biocidal activity against a broad range of Gram-positive and Gram-negative microorganisms, yeast, molds, and viruses (HE et al., 2016; PETERS et al., 2016). Nanoparticles were used 
in animal feed supplements, equipment disinfectants, refrigerators and cutting boards, nano-clothes, air and water filters, packing, and monitoring of biological contaminants (KING et al., 2018). Problems with the use of nanotechnology for the animal food chain include the costs and potential adverse effects of nanomaterials on mammalian health and the environment (BRADLEY et al., 2011; KING et al., 2018).

\section{Diagnostic applications}

Nanoparticles may contain gold dots, perfluorocarbons, and liposomes as imaging agents to detect specific cell types (MATTEUCCI et al., 2000; BENTOLILA et al., 2009). In imaging-based diagnosis, nanoparticles increase the resolution of images, thus enhancing the sensitivity and rapidity of detection of lesions. Further, they are specific biomarkers of pathogens (SMITH et al., 2012). When infectious animal diseases caused by pathogenic microorganisms threaten public health, pathogen detection is an important step in the diagnosis as it enables the successful treatment of these diseases (VIDIC et al., 2017).

New diagnostic assays have been developed for ligand functional nanoparticles with biological molecules such as antibodies, peptides, proteins, and nucleic acids (DRISKELL et al., 2005; LUCHINI et al., 2010; CHAO et al., 2016). In spectroscopy, flow cytometry, and histological methods, nanotechnology enhances the sensitivity of the test by providing an appropriate tool for diagnosis. Moreover, this technology allows the mapping of molecular profiles associated with diseases (HALFPENNY et al., 2010).

Nanosensors have great potential in animal production areas and inspection of products of animal origin due to their ability to measure and distinguish a substance from an organic material or tissue. This has enabled the detection of microbial agents, organophosphate compounds, and antibiotics in the $\beta$-lactam group (MACHADO et al., 2014; HANAFY, 2018). Nanoshells, which are examples of nanosensors, can be made from optically tunable nanoparticles manufactured from a dielectric center covered with an ultrathin metallic layer. This makes them potential candidates for use in the expeditious diagnosis and detection of tumors. Their mechanism results from their infusion into the animal's circulation system with focused operators connected, to search for and append to the surface receptors of tumor cells. This illuminates the body with infrared light, thereby increasing the cell temperature and demolishing the tumor (HANAFY, 2018).

In addition, diagnostic methods in veterinary medicine using nanoparticles validated for the detection of pathogens have been reported. These include viral agents such as Newcastle disease, poxvirus goat (YUAN et al., 2009), avian influenza, foot-and-mouth disease, bovine respiratory syncytial viruses, and bluetongue and epizootic hemorrhagic (VIDIC et al., 2017), bacterial agents such as Mycobacterium avium subsp. paratuberculosis in fecal samples (KUMANAN et al., 2009), Escherichia coli, Salmonella spp., Clostridium perfringens, Campylobacter spp., Mycoplasma spp., other bovine mastitis pathogens, and protozoans such as Eimeria spp. (VIDIC et al., 2017).

An example of a rapid, sensitive, and inexpensive test available in veterinary medicine is the diagnostic method for Mycobacterium bovis, which is based on an electronic nose (NA-NOSE) that is capable of distinguishing between positive and negative animals in serum samples (FEND et al., 2005).

\section{Reproduction}

Nanotechnology is an important tool that could benefit the livestock industry, particularly through post-collection manipulation of semen, routinely used for artificial insemination. It could potentially revolutionize the global livestock breeding industry (FEUGANG et al., 2019). In reproductive biology, nanoparticles have been reported to increase the longevity of spermatozoa, improve male fertility, and select the best spermatozoa for insemination and semen purification (FALCHI et al., 2016; DURFEY et al., 2017; FEUGANG et al., 2019). A nanotube embedded under the skin can provide constant estimation of changes in the blood estradiol level (O'CONNELL et al., 2002), thus detecting estrus by close infrared fluorescence (O'CONNELL et al., 2002; HANAFY, 2018). In the future, it will be possible to distinguish the best reproducers and detect hereditary diseases using nanotechnology (HANAFY, 2018).

\section{Vaccine}

Compared to conventional vaccines, formulations containing nanoparticles may reduce the frequency of vaccine doses and restrict the handling of domestic and wild animals (AUCOUTURIER et al., 2001; NORDLY et al., 2009).

The immunostimulatory activity of nanoscale materials has been attributed to antigen presentation at the depot effect, stability, conformational integrity, slow release, and prolonged exposure to antigens. Additional mechanisms are associated with enhancement of the innate immune response and release of soluble mediators (cytokines, 
chemokines, and immunomodulatory molecules) that regulate the immune response (LOOK et al., 2010).

Nanoparticles, nanoemulsions, and nanotubes can be very useful in vaccinology as entrainment mechanism antigens, adjuvants, and immunomodulators of the immune system (SMITH et al., 2012). In veterinary medicine, cost, stability, facility of administration, bioavailability, and biodegradability are some essential characteristics for applicability and possible implementation of nanotechnology, including as immunobiological agents (AUCOUTURIER et al., 2001; DURAN et al., 2010).

\section{Implications of nanostructures}

Careful assessment of the use of nanostructures for animals, people, and the environment is essential for the development and safe use of nanostructured compounds (QUINA, 2004; O'BRIEN et al., 2010). Thus, as the biological and physicochemical properties of nanostructures vary, their toxicity may be affected by different factors, including the chemical composition, electrical charge, size, and shape of the material used for the development of nanostructures, among others (CARD et al., 2011).

The evaluation of nanostructure formulation security requires a combination of in vitro and in vivo research. A preliminary step is to evaluate in vitro cytotoxicity, genotoxicity, influence of nanostructures on cell signaling, and other cellular functions using cell culture models and analysis of gene expression in cells (SCHRAND et al., 2010). When internalized in cells, nanomaterials can originate reactive oxygen species, surpassing the ability of antioxidant enzymes to maintain the balance of intracellular oxidation-reduction reactions, causing oxidative stress, one of the main factors of cytotoxicity caused by these nanoparticles (WELLS et al., 2009; PASCHOALINO et al., 2010). Therefore, the absorption, distribution, metabolism, and excretion of each nanostructure formulation should be defined by pharmacokinetic, pharmacodynamic, and toxicokinetic studies (CHEN et al., 2006; JI et al., 2007; SZEBENI et al., 2007; HO et al., 2013).

Non-biodegradable nanostructures, particularly inorganic ones, may be associated with side effects. Further, they have greater potential for tissue accumulation than biodegradable nanostructures. However, biodegradable nanostructures may exhibit toxicity due to biodegradation of the product or their metabolites (DURÁN et al., 2010). Thus, the toxicity of nanostructured compounds needs to be further evaluated, particularly the implications for the environment. In this sense, ecotoxicity is considered one of the main challenges to be addressed in an interdisciplinary way to understand the behavior of nanomaterials in the environment (BOTTERO et al., 2015).

\section{Nanotechnology in veterinary medicine in Brazil}

As presented, nanotechnological innovations have been used in veterinary medicine with different applications and have been reported by several researchers (IRACHE et al., 2011; UNDERWOOD et al., 2012; EGUCHI et al., 2013).

In Brazil, one of the world's agricultural commodity powerhouses, livestock plays an important economic, environmental and social role (FERRAZ et al., 2010; VICENSOTTI et al., 2019). Since 2009, with the support of the Ministry of Science, Technology, Innovations and Communications, the Nanotechnology Laboratory for Agribusiness (LNNA) at the Empresa Brasileira de Pesquisa Agropecuária (EMBRAPA), located in São Carlos city, in São Paulo State, is performing research in collaboration with EMBRAPA and other public research institutions and private companies. LNNA is a reference center that enables the development of research projects of interest to agribusiness. However, in veterinary medicine, the research topics include biosensors for the diagnosis of animal diseases, veterinary drugs, and functional food packaging (EMPRAPA, 2012).

Nanotechnology applied in veterinary medicine helps impart greater safety and speed in diagnoses, improves treatment efficiency using lower doses of medication, and thus reduces costs. It also contributes to the reduction in residual drug levels, mainly in products of animal origin (UNDERWOOD et al., 2012; VIDIC et al., 2017). However, this technology can improve the competitiveness and sustainability of Brazilian agribusiness, seeking to improve the quality of products and processes, and the development of new uses for agricultural products (MATTOSO et al., 2005; EMBRAPA, 2012).

Since, the nanotechnology market has shown to be highly promising, new products and applications are launched in practically all sectors and at an increasing speed. According to information obtained from the StatNano website database, 231 agricultural technological products are currently available on the world market, these being compounds for food supplementation, disinfectants for birds, livestock and aquaculture, vaccines and pharmacological treatment, made available by 75 companies, distributed in 26 countries (STATNANO, 2021). Brazil, together with India, Germany, the United Kingdom, the United States of America (USA), Vietnam, Taiwan, China, Malaysia, and the 
Netherlands are the countries most active in promoting nanotechnology for the prosperity of agriculture. However, the USA is the country that most invests in this new technology, offering 3,056 products, varying in 433 sectors and 695 companies involved, 22 of which are agricultural products, involving 12 companies. In comparison, Brazil has 186 products, varying in 58 sectors and 90 companies, of these, nine products are from the agricultural sector, which involve eight companies active in this sector (STATNANO, 2021).

However, basic and applied research in the field of veterinary medicine is growing, and we list the main nanotechnology studies related to this sector in Brazil (Table 1). Although, still incipient,

Table 1 - Different applications of nanotechnology in veterinary medicine in Brazil during the period 2013 to 2020.

\begin{tabular}{|c|c|c|c|}
\hline Application & Description & Nanostructure & References \\
\hline Anesthesiology & Use of propofol & Nanoemulsion & GALL et al., 2013 \\
\hline Surgery & Bone application & Nanostructure & COSTA et al., 2015 \\
\hline \multirow{2}{*}{ Diagnostic } & Leishmania infantum & Nanoparticle & ROSA et al., 2013 \\
\hline & Actinobacillus pleuropneumoniae & Nanoparticle & BRANDÃO et al., 2014 \\
\hline \multirow{17}{*}{$\begin{array}{l}\text { Pharmacology/ } \\
\text { Therapeutics }\end{array}$} & $\begin{array}{l}\text { In vitro sensitivity of Staphylococcus spp. causing } \\
\text { mastitis in goats }\end{array}$ & Nanoparticle & OLIVEIRA et al., 2013 \\
\hline & In vitro susceptibility of Rhodococcus equi & $\begin{array}{l}\text { Nanocapsules and } \\
\text { nanoemulsions }\end{array}$ & SAGAVE et al., 2015 \\
\hline & In vitro susceptibility of Pythium insidiosum & $\begin{array}{c}\text { Nanoemulsion } \\
\text { Nanoparticle }\end{array}$ & $\begin{array}{l}\text { VALENTE et al., } 2016 \\
\text { VALENTE et al., } 2019\end{array}$ \\
\hline & Experimental pythiosis & Nanoparticle & VALENTE et al., 2020 \\
\hline & $\begin{array}{c}\text { Effect of curcumin on treatment and energetic } \\
\text { metabolism of gerbils infected by Listeria } \\
\text { monocytogenes }\end{array}$ & Nanocapsules & JAGUEZESKI et al., 2019 \\
\hline & $\begin{array}{l}\text { Nematicidal activity of silver nanoparticles from } \\
\text { the fungus Duddingtonia flagrans }\end{array}$ & Nanoparticle & BARBOSA et al., 2019 \\
\hline & $\begin{array}{l}\text { In vitro antimicrobial efficacy of nanopropolis for } \\
\text { mastitis treatment }\end{array}$ & Nanoparticle & TRONCARELLI et al., 2014 \\
\hline & Treatment subclinical mastitis of sheep & Nanoparticle & SANTANA et al., 2016 \\
\hline & $\begin{array}{l}\text { In vitro sensitivity of Staphylococcus aureus } \\
\text { causing mastitis in cows and goats }\end{array}$ & Nanoparticle & ACOSTA et al., 2020 \\
\hline & $\begin{array}{l}\text { In vitro sensitivity of Prototheca spp. causing } \\
\text { mastitis in cows }\end{array}$ & Nanoparticle & ELY et al., 2020 \\
\hline & $\begin{array}{l}\text { In vitro susceptibility of Aeromonas hydrophila, } \\
\text { Edwardsiella tarda and Streptococcus iniae }\end{array}$ & Nanoparticle & LUIS, 2017 \\
\hline & Gastrointestinal nematodes & Nanocapsules & RIBEIRO et al., 2014 \\
\hline & Trypanosoma evansi treatment & Nanocapsules & DO CARMO et al., 2015 \\
\hline & $\begin{array}{l}\text { Photodynamic therapy of cutaneous } \\
\text { hemangiosarcoma in dogs }\end{array}$ & Nanoemulsion & ROCHA et al., 2019 \\
\hline & $\begin{array}{l}\text { In vitro and vivo trypanocidal effect of } \\
\qquad(-)-\alpha \text {-bisabolol }\end{array}$ & $\begin{array}{l}\text { Solid lipid } \\
\text { nanoparticles }\end{array}$ & BALDISSERA et al., 2016 \\
\hline & $\begin{array}{c}\text { Suppress hepatic cellular damage and impaired } \\
\text { bioenergetics caused by nerolidol in Oreochromis } \\
\text { niloticus }\end{array}$ & Nanospheres & BALDISSERA et al., 2020b \\
\hline & $\begin{array}{l}\text { Improves therapeutic efficacy of Melaleuca } \\
\text { alternifolia in experimentally infected Rhamdia } \\
\text { quelen with Pseudomonas aeruginosa }\end{array}$ & Nanocapsules & SOUZA et al., 2017 \\
\hline \multirow{3}{*}{$\begin{array}{l}\text { Dietary } \\
\text { supplementation }\end{array}$} & Digestibility of nutrients & Nanoparticles & $\begin{array}{l}\text { MOSS et al., 2017; } \\
\text { FIGUEIREDO et al., } 2019\end{array}$ \\
\hline & $\begin{array}{l}\text { Nerolidol improves growth, antioxidant status and } \\
\text { fillet fatty acid profiles in Oreochromis niloticus }\end{array}$ & Nanospheres & BALDISSERA et al., 2020 \\
\hline & $\begin{array}{l}\text { Diphenyl diselenide in silver catfish feed enhance } \\
\text { growth, improve muscle antioxidant/oxidant } \\
\text { status and increase selenium deposition }\end{array}$ & Nanocapsules & BALDISSERA et al., 2020a \\
\hline
\end{tabular}

Ciência Rural, v.52, n.6, 2022. 
nanotechnology in veterinary medicine in Brazil has evolved gradually in the last seven years, mainly in the development of therapeutic products for the treatment of infections caused by different pathogens. Additionally, it is observed that most studies are related to research and technological innovation projects developed in educational institutions.

\section{CONCLUSION}

Nanotechnology has several benefits to different fields of industry and science, including human, animal and environmental areas. In veterinary medicine, the use of nanostructures in the pharmacological and immunological areas is promising. In Brazil, the use of nanotechnology in veterinary medicine; although incipient, has demonstrated many possibilities for basic and applied research and numerous advances in animal production and health, especially in the area of pharmacological therapies, which has provided promising treatments for diseases with an unfavorable prognosis.

We emphasized that nanotechnology is a recent and promising science that has been breaking many paradigms, and still needs studies to validate its safe use in veterinary medicine. Therefore, aspects related to ecotoxicity, as well as bioaccumulation of nanoparticles in animal and plant tissues must be evaluated in order to guarantee the safety of nanostructured substances. Regarding future perspectives, we believed that greater investment in science and technology could contribute to the advancement and strengthening of nanotechnology in Brazil.

\section{ACKNOWLEDGEMENTS}

This research was supported by Conselho Nacional de Desenvolvimento Científico e Tecnológico (CNPq) [Grant number 420538/2018-6]; Fundação de Amparo à Pesquisa do Estado do Rio Grande do Sul [Grant number PqG/ FAPERGS 27293.414.15435.20062017] and Coordenação de Aperfeiçoamento de Pessoal de Nível Superior (CAPES) [Grant number/Finance code 001]

\section{DECLARATION OF CONFLICT OF INTEREST}

None of the authors of this paper has a financial or personal relationship with other people or organisations that could inappropriately influence or bias the content of the paper.

\section{AUTHORS' CONTRIBUTIONS}

The authors contributed equally to the manuscript.

\section{REFERENCES}

ACOSTA, A. C. et al. Antibacterial behavior of polypyrrole nanoparticles against Staphylococcus aureus isolated from cows and goats with mastitis. Arquivos Brasileiros de Medicina Veterinária e Zootecnia, v.72, n.03, p.1047-1050, 2020. Available from: <http://www.scielo.br/scielo.php?script=sci_arttext\&pid=S 010209352020000301047\&lng=en\&nrm=iso $>$. Accessed: Jan. 08, 2021. doi: 10.1590/1678-4162-10384.

ALLEMANN, E. et al. Drug-loaded nanoparticles - Preparation methods and drug targeting issues. European Journal Pharmaceutical and Biopharmaceutic, v.39, p.173-191, 1993.

ALI, M. et al. Therapeutic efficacy of poly (lactic-co-glycolic acid) nanoparticles encapsulated ivermectin (nano-ivermectin) against brugian filariasis in experimental rodent model. Parasitology Research, v.113, p.681-691, 2014. Available from: <https://link. springer.com/article/10.1007/s00436-013-3696-5>. Accessed: Jan. 08, 2021. doi: 10.1007/s00436-013-3696-5.

AUCOUTURIER, J. et al. Adjuvants designed for veterinary and human vaccines. Vaccine, v.19, p.2666-2672, 2001. Available from: <https://pubmed.ncbi.nlm.nih.gov/11257407/>. Accessed: Jan. 08, 2021. doi: 10.1016/s0264-410x(00)00498-9.

BALDISSERA, M. D. et al. A nanotechnology based new approach for Trypanosoma evansi chemotherapy: In vitro and vivo trypanocidal effect of (-)- $\alpha$-bisabolol, Experimental Parasitology, v.170, p.156-160, 2016. Available from: <https://pubmed.ncbi. nlm.nih.gov/27693361/>. Accessed: Jan. 21, 2021. doi: 10.1016/j. exppara.2016.09.018

BALDISSERA, M. D. et al. Dietary supplementation with nerolidol nanospheres improves growth, antioxidant status and fillet fatty acid profiles in Nile tilapia: Benefits of nanotechnology for fish health and meat quality. Aquaculture, v.516, 734635, 2020. Available from: <https://www.sciencedirect.com/science/ article/abs/pii/S0044848619325670>. Accessed: Jan. 21, 2021. doi: 10.1016/j.aquaculture.2019.734635.

BALDISSERA, M. D. et al. Diphenyl diselenide loaded nanocapsules in silver catfish feed enhance growth, improve muscle antioxidant/oxidant status and increase selenium deposition: Advantages of nanotechnology for fish health. Aquaculture Research, v.51, p.4196-4205, 2020a. Available from: <https:// onlinelibrary.wiley.com/doi/10.1111/are.14761>. Accessed: Jan. 21, 2021. doi: 10.1111/are.14761.

BALDISSERA, M. D. et al. Nanospheres as a technological alternative to suppress hepatic cellular damage and impaired bioenergetics caused by nerolidol in Nile tilapia (Oreochromis niloticus). Naunyn-Schmiedeberg's Archives of Pharmacology, v.393, p.751-759 2020b. Available from: <https://pubmed.ncbi. nlm.nih.gov/31953674/>. Accessed: Jan. 21, 2021. doi: 10.1007/ s00210-020-01824-2.

BAKKER-WOUDENBERG, I. M. et al. Long-circulating sterically stabilized liposomes in the treatment of infections. Methods in Enzymology, v.391, p.228-260, 2005. Available from: <https:// pubmed.ncbi.nlm.nih.gov/15721385/>. Accessed: Dec. 20, 2020. doi: 10.1016/S0076-6879(05)91014-8.

BARBOSA, A. C. M. et al. Nematicidal activity of silver nanoparticles from the fungus Duddingtoniaflagrans. International Journal of Nanomedicine, v.14, p.2341-2348, 2019. Available 
from: <https://pubmed.ncbi.nlm.nih.gov/31040660/>. Accessed: Dec. 20, 2020. doi: 10.2147/IJN.S193679.

BENTOLILA, L. A. et al. Quantum dots for in vivo smallanimal imaging. Journal of Nuclear Medicine, v.50, n.04, p.493-496, 2009. Available from: <https://pubmed.ncbi.nlm. nih.gov/19289434/>. Accessed: Dec. 09, 2020. doi: $10.2967 /$ jnumed.108.053561.

BOTTERO, J. Y. et al. Nanotechnology, global development in the frame of environmental risk forecasting. A necessity of interdisciplinary researches. Comptes Rendus Geoscience, v.347, p.35-42, 2015. Available from: <https://www.sciencedirect.com/ science/article/pii/S1631071314001497>. Accessed: Nov. 15, 2020. doi: $10.1016 /$ j.crte.2014.10.004

BRADLEY, E. L. et al. Applications of nanomaterials in food packaging with a consideration of opportunities for developing countries. Trends in Food Science \& Technology, v.22, p.604 610, 2011. Available from: <https://www.sciencedirect.com/ science/article/abs/pii/S0924224411000033>. Accessed: Dec. 09, 2020. doi: 10.1016 / j.tifs.2011.01.002.

BRANDÃO, L. N. S. et al. Standardization of unmodified gold nanoparticle (AuNPs) for detection of Actinobacillus pleuropneumoniafe in swine lungs. Pesquisa Veterinária Brasileira, v.34, n.7, p.621-625, 2014. Available from: < https://www.scielo.br/j/pvb/a/H8jfhKbHqHRsfKKgFcmcNVv/ abstract/?lang=en $>$. Accessed: Nov. 15, 2020.

CARD, J. W. et al. An appraisal of the published literature on the safety and toxicity of food-related nanomaterials. Critical Reviews in Toxicology, v.41, p.22-49, 2011. doi: Available from: <https:// pubmed.ncbi.nlm.nih.gov/21077788/> . Accessed: Dec. 09, 2020. doi: 10.3109/10408444.2010.524636.

CHAO, J. et al. DNA nanotechnology-enabled biosensors. Biosensors and Bioelectronics, v.76, p.68-79, 2016. Available from: $\quad<$ https://www.sciencedirect.com/science/article/abs/pii/ S0956566315302578>. Accessed: Dec. 20, 2020. doi: 10.1016/j. bios.2015.07.007.

CHEN, Z. et al. Acute toxicological effects of copper nanoparticles in vivo. Toxicology Letters, v.163, p.109-120, 2006. Available from: <https://www.sciencedirect.com/science/article/abs/pii/ S0378427405003176>. Accessed: Dec. 20, 2020. doi: 10.1016/j. toxlet.2005.10.003.

CHEN, Y. et al. Multifunctional nanoparticles delivering small interfering RNA and doxorubicin overcome drug resistance in cancer. The Journal of Biological Chemistry, v.285, p.2263922650, 2010. Available from: <https://www.jbc.org/article/S00219258(20)60297-6/fulltext>. Accessed: Jan. 08, 2021. doi: 10.1074/ jbc.M110.125906.

CORDEIRO, C. et al. Antibacterial efficacy of gentamicin encapsulated in $\mathrm{pH}$-sensitive liposomes against an in vivo Salmonella enterica serovar Typhimurium intracellular infection model. Antimicrobial Agents and Chemotherapy, v.44, p.533-539, 2000. Available from: $<$ https://aac.asm.org/content/44/3/533.abstract>. Accessed: Dec. 09, 2020. doi: 10.1128/aac.44.3.533-539.2000.

COSTA, B. D. et al. Bone formation and osteointegration of micro and nanostructured biomaterial in sheep. Pesquisa Veterinária Brasileira, v.35, p.177-187, 2015. Available from: $<$ https://www. scielo.br/scielo.php?script=sci_abstract\&pid=S0100-736X2015 000200177\&lng=pt\&nrm=isso $>$. Accessed: Dec. 08, 2020. doi: 10.1590/S0100-736X2015000200015.

COUVREUR, P. et al. Nanoparticles and microparticles for the delivery of polypeptides and proteins. Advanced Drug Delivery Reviews, v.10, p.141-162, 1993. Available from: <https://www. sciencedirect.com/science/article/abs/pii/0169409X93900467>. Accessed: Nov. 15, 2020. doi: 10.1016/0169-409X(93)90046-7.

DANHIER, F. et al. To exploit the tumor microenvironment: Passive and active tumor targeting of nanocarriers for anti-cancer drug delivery. Journal of Controlled Release, v.148, p.135-146, 2010. Available from: <https://pubmed.ncbi.nlm.nih.gov/20797419/>. Accessed: Jan. 08, 2021. doi: 10.1016/j.jconrel.2010.08.027.

DO CARMO, G. M. et al. Effect of the treatment with Achyrocline satureioides (free and nanocapsules essential oil) and diminazeneaceturate on hematological and biochemical parameters in rats infected by Trypanosoma evansi. Experimental Parasitology, v.149, p.39-46, 2015. Available from: <https:// pubmed.ncbi.nlm.nih.gov/25499512/>. Accessed: Jan. 08, 2021. doi: 10.1016/j.exppara.2014.12.005.

DRISKELL, J. D. et al. Low-level detection of viral pathogens by a surface-enhanced Raman scattering based immunoassay. Analytical Chemistry, v.77, p.6147-6154, 2005. Available from: $<$ https://pubmed.ncbi.nlm.nih.gov/16194072/>. Accessed: Nov. 15, 2020. doi: 10.1021/ac0504159.

DURÁN, N., et al. Nanocrystal technology in pharmaceuticals. Química Nova, v.33, p.151-158, 2010. Available from: $<$ https:// www.scielo.br/scielo.php? script $=$ sci_arttext\&pid $=$ S010040422010000100028\&lng=pt\&nrm=iso >. Accessed: Jan. 13, 2021. doi: 10.1590/S0100-40422010000100028.

DURFEY, C. L. et al. Nanotechnology-based selection of boar spermatozoa: growth development and health assessments of produced offspring. Livestock science, v.205, p.137-142, 2017. Available from: <https://www.sciencedirect.com/science/article/ abs/pii/S1871141317302895>. Accessed: Jan. 08, 2021. doi: 10.1016/j.livsci.2017.09.024.

EDWARDS, K. A et al. Analyses of liposomes. Talanta, v.68, p.1432-1441, 2006. Available from: <https://www.sciencedirect. com/science/article/abs/pii/S0039914005005436>. Accessed: Dec. 20, 2020. doi: 10.1016/j.talanta.2005.08.031.

EGUCHI, E. S. et al. O caminho da nanotecnologia na produção animal brasileira. Pubvet, v.07, n.08, p.01-12, 2013. Available from: $<$ http://pubvet.com.br/artigo/592/o-caminho-da-nanotecnologiana-produccedilatildeo-animal-brasileira $>$. Accessed: Dec. 09, 2020. doi: $10.22256 /$ pubvet.v7n8.1528.

ELY, V. L. et al. In vitro algicidal effect of polypyrrole on Prototheca species isolates from bovine mastitis. Medical Mycology, v.58, p.1114-1119, 2020. Available from: <https://academic.oup.com/ mmy/article-abstract/58/8/1114/5828677?redirectedFrom=fullte xt>. Accessed: Dec. 09, 2020. doi: 10.1093/ mmy / myaa021.

EMBRAPA, Empresa Brasileira de Pesquisa Agropecuária. Ministério da Agricultura, Pecuária e Abastecimento. Nanotecnologia: obter o máximo do mínimo. São Carlos, SP, 2012. Online. Available from: <https://www. agropediabrasilis.cnptia.embrapa.br/documents/181963/332763/ FolderNanotecnologiaPortugues.pdf/138fdb67-88b9-407b-9d9f61552cc1849a>. Accessed: Dec. 09, 2020. 
FAHMY, T. M. et al. Surface modification of biodegradable polyesters with fatty acid conjugates for improved drug targeting. Biomaterials, v.26, p.5727-5736, 2005. Available from: $<$ https:// europepmc.org/article/med/15878378>. Accessed: Jan. 21, 2021. doi: 10.1016/j.biomaterials.2005.02.025.

FALCHI, L. et al. Cerium dioxide nanoparticles did not alter the functional and morphologic characteristics of ram sperm during short-term exposure. Theriogenology, v.85, p.1274-1281, 2016. Available from: <https://www.sciencedirect.com/science/article/ abs/pii/S0093691X15006846>. Accessed: Dec. 20, 2020. doi: 10.1016/j.theriogenology.2015.12.011.

FEND, R. et al. Use of an electronic nose to diagnose Mycobacterium bovis infection in badgers and cattle. Journal of Clinical Microbiology, v.43, p.1745-1751, 2005. Available from: $<\mathrm{https}$ ://jcm.asm.org/content/43/4/1745.short>. Accessed: Dec. 20, 2020. doi: 10.1128/JCM.43.4.1745-1751.2005.

FERREIRA, H. S. et al. Nanotechnology: general aspects and potential applications in catalysis. Química Nova, v.32, p.18601870, 2009. Available from: <https://www.scielo.br/scielo. php?script $=$ sci_arttext\&pid $=$ S0100-40422009000700033 $>$. Accessed:Dec.20,2020. doi:10.1590/S0100-40422009000700033.

FERRAZ, J. B. et al. Production systems - An example from Brazil. Meat Science, v.84, p.238-243, 2010. Available from: $\quad<\mathrm{https}: / / \mathrm{www} . s c i e n c e d i r e c t . c o m /$ science/article/abs/pii/ S0309174009001648>. Accessed: Dec. 09, 2020. doi: 10.1016/j. meatsci.2009.06.006

FEUGANG, J. M. et al. Treatment of boar sperm with nanoparticles for improved fertility. Theriogenology, v.137, n.01, p.75-81, 2019. Available from: <https://pubmed.ncbi.nlm. nih.gov/31204016/>. Accessed: Jan. 08, 2021. doi: 10.1016/j. theriogenology.2019.05.040.

FIGUEIREDO, M. R. P. et al. Use of indigestible markers to estimate the apparent dry matter digestibility of diets containing a cocoa by-product. Semina: Ciências Agrárias, v.40, n.06, p.27712782, 2019. Available from: <http://dx.doi.org/10.5433/16790359.2019v40n6p2771>. Accessed: Jan. 08, 2021. doi: 10.5433/1679-0359.2019v40n6p2771.

FEYNMAN, R. P. There's plenty of room at the bottom Engineering and Science, v.23, p.22-36, 1960. Available from: $<$ Microsoft Word - Feynman.doc (nanoparticles.org) > Accessed: Nov. 15, 2020.

FREITAS, RA, J.R. What is nanomedicine? Nanomedicine, v.01, p.02-09, 2005. Available from: <https://www.sciencedirect.com/ science/article/abs/pii/S1549963404000048>. Accessed: Nov. 15, 2020. doi: 10.1016 / j.nano.2004.11.003.

GALL, G. O. et al. Anesthetic induction with nanoemulsion or lipid emulsion of propofol during consecutive days in cats. Ciência Rural, v.43, p.2011-2017, 2013. Available from: $<$ https://www.scielo.br/scielo.php?script=sci_arttext\&pid $=$ S0103-84782013001100015 $>$. Accessed: Dec. 09, 2020. doi 10.1590/S0103-84782013001100015.

GREENWOOD, D. L. V. et al. Vaccination against foot-and-mouth disease virus using peptides conjugated to nano-beads. Vaccine, v.26, p.2706-2713, 2008. Available from: <https://pubmed.ncbi. nlm.nih.gov/18448209/>. Accessed: Dec. 20, 2020. doi: 10.1016/j. vaccine. 2008.03 .025
HALFPENNY, K. C. et al. Nanoparticle detection of respiratory infection. Nanomedicine and Nanobiotechnology, v.02, p.277290, 2010. Available from: <https://onlinelibrary.wiley.com/doi/ full/10.1002/wnan.83>. Accessed: Dec. 09, 2020. doi: 10.1002/ wnan. 83 .

HANAFY, M. H., 2018. Myconanotechnology in veterinary sector: Status quo and future Perspectives. International Journal of Veterinary Science and Medicine, v.06, p.270-273, 2018. Available from: <https://pubmed.ncbi.nlm.nih.gov/30564608/>. Accessed: Nov. 15, 2020. doi: 10.1016/j.ijvsm.2018.11.003.

HE, X. et al. Nanotechnology in food science: Functionality, applicability, and safety assessment. Journal of Food and Drug Analysis, v.24, p.671-681, 2016. Available from: <https://www. sciencedirect.com/science/article/pii/S1021949816300758>. Accessed: Dec. 20, 2020. doi: 10.1016/j.jfda.2016.06.001.

HO, C. C. et al. Quantum dot 705, a cadmium-based nanoparticle, induces persistent inflammation and granuloma formation in the mouse lung. Nanotoxicology, v.07, p.105-115, 2013. Available from: <https://pubmed.ncbi.nlm.nih.gov/22107365/>. Accessed: Jan. 08, 2021. doi: 10.3109/17435390.2011.635814.

HOFHEINZ, R. D. et al. Liposomal encapsulated anti-cancer drugs. Anti-Cancer Drugs, v.16, p.691-707, 2005. Available from: $<$ https://pubmed.ncbi.nlm.nih.gov/16027517/>. Accessed: Dec. 09, 2020. doi: 10.1097/01.cad.0000167902.53039.5a.

IIJIMA, S. Helical microtubules of graphitic carbon. Nature, v.354, p.56-58, 1991. Available from: <https://www.nature. com/articles/354056a0 $>$. Accessed: Dec. 09, 2020. doi: $10.1038 / 354056 \mathrm{a} 0$

IRACHE, J. M. et al. Nanomedicine: novel approaches in human and veterinary therapeutics. Veterinary Parasitology, v.180, p.47-71, 2011. Available from: <https://pubmed.ncbi.nlm. nih.gov/21680101/>. Accessed: Nov. 15, 2020. doi: 10.1016/j. vetpar.2011.05.028

ISHIHARA, T. et al. Preparation and characterization of a nanoparticulate formulation composed of PEG-PLA and PLA as anti-inflammatory agents. International Journal of Pharmaceutics, v.385, p.170-175, 2010. Available from: <https:// pubmed.ncbi.nlm.nih.gov/19837147/>. Accessed: Dec. 09, 2020. doi: 10.1016/j.ijpharm.2009.10.025.

HASSAN, D. et al. Antiprotozoal activity of silver nanoparticles against Cryptosporidium parvum oocysts: New insights on their feasibility as a water disinfectant. Journal of Microbiological Methods, v.22, 105698, 2019. Available from: <https://pubmed. ncbi.nlm.nih.gov/31446036/>. Accessed: Dec. 20, 2020. doi: 10.1016/j.mimet.2019.105698.

JAGIELSKI, T. et al. The activity of silver nanoparticles against microalgae of the Prototheca genus. Nanomedicine, v.13, p.1025-1036, 2018. Available from: <https://pubmed.ncbi.nlm. nih.gov/29790400/>. Accessed: Jan. 08, 2021. doi: 10.2217/nnm2017-0370.

JAGUEZESKI, A. M. et al. Effect of free and nano-encapsulated curcumin on treatment and energetic metabolism of gerbils infected by Listeria monocytogenes. Microbial Pathogenesis, v.134, 103564, 2019. Available from: <https://pubmed.ncbi.nlm. nih.gov/31163248/>. Accessed: Jan. 08, 2021. doi: 10.1016/j. micpath.2019.103564. 
JI, J. H. et al. Twenty-eight-day inhalation toxicity study of silver nanoparticles in Sprague-Dawley rats. Inhalation Toxicology, v.19, p.857-871, 2007. Available from: <https://pubmed. ncbi.nlm.nih.gov/17687717/>. Accessed: Jan. 08, 2021. doi: $10.1080 / 08958370701432108$

KHAN, Y. A. et al. Anthelmintic effect of biocompatible zinc oxide nanoparticles ( $\mathrm{ZnO} \mathrm{NPs})$ on Gigantocotyle explanatum a neglected parasite of Indian water buffalo. PLoS One, v.10, e0133086, 2015. Available from: <https://journals.plos.org/ plosone/article?id=10.1371/journal.pone.0133086>. Accessed: Jan. 08, 2021. doi: 10.1371/journal.pone.0133086.

KING, T. et al. Nanotechnology in the food sector and potential applications for the poultry industry. Trends in Food Science \& Technology, v.72, p.62-73, 2018. Available from: <https://www. sciencedirect.com/science/article/pii/S0924224417303448>. Accessed: Jan. 21, 2021. doi: 10.1016/ j.tifs.2017.11.015.

KROTO, H. W. et al.C60: Buckminsterfullerene. Nature, v.318, p.162-163, 1985. Available from: <https://www.nature com/articles/318162a0\#citeas $>$. Accessed: Nov. 15, 2020. doi: $10.1038 / 318162 \mathrm{a} 0$

KROUBI, M. et al. Development of a nanoparticulate formulation of diminazene to treat African trypanosomiasis. Nanotechnology, v.21, p.01-08, 2010. Available from: <https://iopscience.iop.org/ article/10.1088/0957-4484/21/50/505102/meta>. Accessed: Jan. 08, 2021. doi: $10.1088 / 0957-4484 / 21 / 50 / 505102$.

KUMANAN, V. et al. A biosensor assay for the detection of Mycobacterium avium subsp. paratuberculosis in fecal samples. Journal of Veterinary Science, v.10, p.35-42, 2009. Available from: <https://pubmed.ncbi.nlm.nih.gov/19255522/>. Accessed: Jan. 08, 2021. doi: 10.4142/jvs.2009.10.1.35.

LEE, J. H. et al. Combination Drug Delivery Approaches in Metastatic Breast Cancer. Journal of Drug Delivery, 2012, 915375. Available from: <https://pubmed.ncbi.nlm.nih.gov/22619725/>. Accessed: Dec. 20, 2020. doi: 10.1155/2012/915375.

LIU, Y. et al. Nanomedicine for drug delivery and imaging: A promising avenue for cancer therapy and diagnosis using targeted functional nanoparticles. International Journal of Cancer, v.120, p.2527-2537, 2007. Available from: <https://onlinelibrary.wiley. com/doi/full/10.1002/ijc.22709>. Accessed: Nov. 15, 2020. doi $10.1002 / \mathrm{ijc} .22709$

LOOK, M. et al. Application of nanotechnologies for improved immune response against infectious diseases in the developing world. Advanced Drug Delivery Reviews, v.62, p.378-393, 2010. Available from: <https://pubmed.ncbi.nlm.nih.gov/19922750/>. Accessed: Dec. 09, 2020. doi: 10.1016/j.addr.2009.11.011.

LUCHINI, A. et al. Nanoparticle technology: Addressing the fundamental roadblocks to protein biomarker Discovery. Current Molecular Medicine, v.10, p.133-141, 2010. Available from: $<$ https://pubmed.ncbi.nlm.nih.gov/20196732/>. Accessed: Dec. 09, 2020. doi: 10.2174/156652410790963268.

LUIS, A. I. S. Nanotecnologia e aquicultura: desenvolvimento de sistemas para controle de doenças baseados em nanopartículas de zeína contendo eugenol e óleos essenciais de alho. 2017. 87f Dissertação (Mestrado) - Curso de Pós-graduação em Ciências Ambientais, Universidade Estadual Paulista "Júlio de Mesquita Filho". Instituto de Ciência e Tecnologia (Câmpus de Sorocaba).
MACHADO, I. R. L. et al. Carbon nanotubes: potential use in veterinary medicine. Ciência Rural, v.44, p.1823-1829, 2014. Available from: $<$ https://www.scielo.br/scielo.php?script=sci_artt ext\&pid=S0103-84782014001001823 > . Accessed: Dec. 20, 2020. doi: $10.1590 / 0103-8478 \mathrm{cr} 20140003$

MAEDA, H. Tumor-selective delivery of macromolecular drugs via the EPR effect: Background and future prospects. Bioconjugate Chemistry, v.21, p.797-802, 2010. Available from: $<$ https://pubmed.ncbi.nlm.nih.gov/20397686/>. Accessed: Jan. 08, 2021. doi: $10.1021 / \mathrm{bc} 100070 \mathrm{~g}$.

MATTEUCCI, M. L. et al. The role of liposomes in drug delivery and diagnostic imaging: A review. Veterinary Radiology and Ultrasound, v.41, p.100-107, 2000. Available from: <https:// pubmed.ncbi.nlm.nih.gov/10779068/>. Accessed: Dec. 09, 2020

MATTOSO, L. H. C. et al. The nanotechnological revolution and the potential for agribusiness. [A revolução nanotecnológica e o potencial para o agronegócio]. Revista de Política Agrícola, v.14, n.04, p.38-46, 2005. Online. Available from: <https://seer. sede.embrapa.br/index.php/RPA/article/view/551>. Accessed: Dec. 09, 2020.

METSELAAR, J. M. et al. Complete remission of experimental arthritis by joint targeting of glucocorticoids with long-circulating liposomes. Arthritis and Rheumatism, v.48, p.2059-2066, 2003. Available from: $<$ https://onlinelibrary.wiley.com/doi/full/10.1002/ art.11140>. Accessed: Dec. 09, 2020. doi: 10.1002/art.11140.

MISHRA, A. et al. Biosynthesis of gold and silver nanoparticles from Candida guilliermondii and their antimicrobial effect against pathogenic bacteria. Journal of Nanoscience and Nanotechnology, v.11, p.243-248, 2011. Available from: $<$ https:// pubmed.ncbi.nlm.nih.gov/21446434/>. Accessed: Jan. 08, 2021. doi: 10.1166/jnn.2011.3265.

MOSS, P. C. B. et al. Validation of Nanolipe ${ }^{\circledR}$ as method to assess the apparent digestibility of nutrients on horses. Arquivos Brasileiros de Medicina Veterinária e Zootecnia, v.69, n.03, p.687-694, 2017. Available from: $\quad<$ https://www.scielo.br/scielo.php?pid=S0102$09352017000300687 \&$ script $=$ sci abstract\&tlng $=p t>$. Accessed: Dec. 20, 2020. doi: $10.1590 / 1678-4162-8270$

NORDLY, P. et al. Status and future prospects of lipid-based particulate delivery systems as vaccine adjuvants and their combination with immunostimulators. Expert Opinion on Drug Delivery, v.06, p.657-672, 2009. Available from: $<$ https://pubmed. ncbi.nlm.nih.gov/19538037/>. Accessed: Dec. 20, 2020. doi: $10.1517 / 17425240903018863$.

O'BRIEN, N. et al. Ranking initial environmental and human health risk resulting from environmentally relevant nanomaterials. Journal of Environmental Science and Health. Part A, Toxic/ Hazardous Substances \& Environmental Engineering, v.45, p.992-1007, 2010. Available from: <https://www.tandfonline.com/ doi/abs/10.1080/10934521003772410>. Accessed: Nov. 15, 2020. doi: $10.1080 / 10934521003772410$.

O'CONNELL, M. J. et al. Band gap fluorescence from individual single-walled carbon nanotubes. Science, v.297, p.593-596, 2002. Available from: <https://pubmed.ncbi.nlm.nih.gov/12142535/>. Accessed: Dec. 09, 2020. doi: 10.1126/science.1072631.

OLIVEIRA, H. P. et al. Antimicrobial activity of silver nanoparticles synthesized by the fungus Curvularia inaequalis. African Journal 
of Biotechnology, v.12, p.2917- 2923, 2013. Available from: $<$ https://academicjournals.org/article/article1380722870_de $\% 20$ Oliveira\%20et\%20al.pdf $>$. Accessed: Jan. 08, 2021. doi: 10.5897/ AJB2013.12375.

PADMAVATHY, N. et al. Enhanced bioactivity of $\mathrm{ZnO}$ nanoparticles-an antimicrobial study. Science and Technology of Advanced Materials, v.09, 035004, 2008. Available from: $<$ https://pubmed.ncbi.nlm.nih.gov/27878001/>. Accessed: Dec. 20, 2020. doi: 10.1088/1468-6996/9/3/035004.

PARVEEN, S. et al. Nanoparticles: a boon to drug delivery, therapeutics, diagnostics and imaging. Nanomedicine: Nanotechnology, Biology and Medicine, v.08, p.147-166, 2012 Available from: <https://pubmed.ncbi.nlm.nih.gov/21703993/>. Accessed: Nov. 15, 2020. doi: 10.1016/j.nano.2011.05.016.

PASCHOALINO, M. P., et al. Nanomaterials and the environment. Química Nova, v.33, n. 2, p.421-430, 2010. Available from: $<$ https://www.scielo.br/scielo.php?script $=$ sci arttext\&pid $=\mathrm{S} 0100$ $40422010000200033 \& \operatorname{lng}=$ pt\&nrm $=$ iso \&tlng $=$ pt $>$. Accessed: May, 05, 2021. doi: 10.1590/S0100-40422010000200033.

PELAZ, B. et al. Diverse applications of nanomedicine. ACS Nano, v.11, p.2313-2381, 2017. Available from: <https://pubmed. ncbi.nlm.nih.gov/28290206/>. Accessed: Nov. 15, 2020. doi: 10.1021/acsnano.6b06040.

PETERS, R. J. et al. Nanomaterials for products and application in agriculture, feed and food. Trends in Food Science \& Technology, v.54, p.155-164, 2016. Available from: $<$ https://www. sciencedirect.com/science/article/abs/pii/S0924224415300467>. Accessed: Nov. 15, 2020. doi: 10.1016/j.tifs.2016.06.008

PROW, T. W. et al. Nanomedicine - nanoparticles, molecular biosensors and targeted gene/drug delivery for combined singlecell diagnostics and therapeutics. Advanced Biomedical and Clinical Diagnostic Systems II, v.5318, p.01-11, 2004. doi: $10.1117 / 12.547922$.

PROW, T. W. et al. Biosensor-controlled gene therapy/drug delivery with nanoparticles for nanomedicine. Proceedingsof SPIE, v.5692, p.199-208, 2005. doi: 10.1117/12.589422.

QUINA, F. H. Nanotecnologia e o meio ambiente: perspectivas e riscos. Química Nova, v.27, p.1028-1029, 2004. Available from: $\quad<$ https://www.scielo.br/scielo.php?script=sci arttext\&pid=S0100-40422004000600031>. Accessed: Nov. 15, 2020. doi: 10.1590/S0100-40422004000600031.

REHMAN, A. et al. In vitro anthelmintic effect of biologically synthesized silver nanoparticles on liver amphistome, Gigantocotyle explanatum. Experimental Parasitology, v.198, p.95-104, 2018. Available from: <https://www.sciencedirect.com/ science/article/abs/pii/S0014489418304624>. Accessed. Jan. 08, 2021. doi: 10.1016/j.exppara.2019.02.005.

RIBEIRO, J. C. et al. Efficacy of free and nanoencapsulated Eucalyptus citriodora essential oils on sheep gastrointestinal nematodes and toxicity for mice. Veterinary Parasitology, v.204, p. 02-08, 2014. Available from: <https://pubmed.ncbi.nlm. nih.gov/24929446/>. Accessed: Dec. 20, 2020. doi: 10.1016/j. vetpar.2014.05.026.

ROCHA, M. S. T. et al. Photodynamic therapy for cutaneous hemangiosarcoma in dogs. Photodiagnosis and Photodynamic
Therapy, v.27, p.39-43, 2019. Available from: <https://www. sciencedirect.com/science/article/abs/pii/S1572100019301735>. Accessed: Dec. 09, 2020. doi: 10.1016/j.pdpdt.2019.05.026.

ROCO, M. C. The long view of nanotechnology development: the National Nanotechnology Initiative at 10 years. Journal of Nanoparticle Research, v.13, p.427-445, 2011. Available from: $<$ https://link.springer.com/article/10.1007/s11051-010-0192-z>. Accessed: Nov. 15, 2020. doi: 10.1007/s11051-010-0192-z.

ROSA, J. M. A. et al. Molecular diagnosis of canine visceral leishmaniasis through the technique of probe gold nanoparticles (AuNPprobes). Semina: Ciências Agrárias, v.34, p.37773786, 2013. Available from: <https://www.redalyc.org/ pdf/4457/445744138006.pdf $>$. Accessed: Jan. 08, 2021. doi: 10.5433/1679-0359.2013v34n6Sup12p3777.

ROSE, J. S. et al. Extended-duration analgesia: Update on microspheres and liposomes. Regional Anesthesia and Pain Medicine, v.30, p.275-285, 2005. Available from: <https:// pubmed.ncbi.nlm.nih.gov/15898031/>.Accessed: Dec. 09, 2020. doi: 10.1016/j.rapm.2005.01.004.

SAGAVE,L.etal.Melaleucaalternifolia activityinnanoformulations and terpinen-4-ol against Rhodococcus equi isolates. Arquivos Brasileiros de Medicina Veterinária e Zootecnia, v.67, p.221226, 2015. Available from: <https://www.scielo.br/scielo. php? script $=$ sci arttext\&pid $=$ S0102-09352015000100221>. Accessed: Dec. 09, 2020. doi: 10.1590/1678-7454.

SAHOO, S. K. et al. Nanotech approaches to drug delivery and imaging. Drug Discovery Today, v.08, p.1112-1120, 2003. Available from: <https://pubmed.ncbi.nlm.nih.gov/14678737/> Accessed: Nov. 15, 2020. doi: 10.1016/s1359-6446(03)02903-9.

SANTANA, R. C. M. et al. Use of nanoparticulated antimicrobians to treat subclinical mastitis of ewes during the dry period. Pesquisa Veterinária Brasileira, v.36, p.826-830, 2016. Available from: $<$ https://www.scielo.br/scielo.php?pid=S0100736X2016000900826\&script $=$ sci_abstract\&tlng=pt $>$. Accessed: Dec. 20, 2020. doi: 10.1590/s0100-736x2016000900006.

SCHAFFAZICK, S. R. et al. Physicochemical characterization and stability of the polymeric nanoparticle systems for Drug administration. Química Nova, v.26, p.726-737, 2003. Available from: $<$ https://www.scielo.br/scielo.php?script $=$ sci arttext\&pid $=$ S0100-40422003000500017>. Accessed: Nov. 15, 2020. doi: 10.1590/S0100-40422003000500017.

SCHRAND, A. M. et al. Metal-based nanoparticles and their toxicity assessment. Nanomedicine and Nanobiotechnology, v.02, p.544-568, 2010. Available from: <https://pubmed.ncbi.nlm.nih. gov/20681021/>. Accessed: Nov. 15, 2020. doi: 10.1002/wnan.103.

SHAKIR, M. et al. Fabrication and characterization of nanoengineered biocompatible n-HA/chitosan-tamarind seed polysaccharide: bioinspired nanocomposites for bone tissue engineering. International Journal of Biological Macromolecules, v.111, p.903-916, 2018. Available from: <https://www.sciencedirect.com/science/article/abs/ pii/S014181301733698X>. Accessed: Dec. 09, 2020. doi: 10.1016/j. ijbiomac.2018.01.035.

SMITH, L. et al. Nanoparticles in Cancer Imaging and Therapy. Journal of Nanomaterials, p.01-07, 2012. Available from: $<$ https://www.hindawi.com/journals/jnm/2012/891318/>. Accessed: Dec. 20, 2020. doi: 10.1155/2012/891318. 
SMITH, D. M. et al. Applications of nanotechnology for immunology. Nature Immunology, v.13, p.592-605, 2013. Available from: <https://www.nature.com/articles/nri3488>. Accessed: Dec. 20, 2020. doi: 10.1038/nri3488.

SOLANS, C. et al. Nanoemulsions. Current Opinion in Colloid \& Interface Science, v.10, p.102-110, 2005. Available from: <https://link.springer.com/referenceworkentry/10.1007 \%2F978-3-642-20665-8 27>. Accessed: Nov. 15, 2020. doi: 10.1007/978-3-642-20665-8 27.

SOUZA, C. F. et al. Nanotechnology improves the therapeutic efficacy of Melaleuca alternifolia essential oil in experimentally infected Rhamdia quelen with Pseudomonas aeruginosa. Aquaculture, v.473, p.169-171, 2017. Available from: $<$ https://www.sciencedirect.com/science/article/abs/pii/ S0044848617301370>. Accessed: Jan. 08, 2021. doi: 10.1016/j. aquaculture.2017.02.014.

STATNANO. 2021. Nanotechnology Products Database (StatNano). Available from: <https://statnano.com/>. Accessed: May, 08, 2021.

SZEBENI, J. et al. Animal models of complement-mediated hypersensitivity reactions to liposomes and other lipidbased nanoparticles. Journal of Liposome Research, v.17, p.107-117, 2007. Available from: <https://pubmed.ncbi. nlm.nih.gov/17613700/>. Accessed: Nov. 15, 2020. doi: $10.1080 / 08982100701375118$.

THAKUR, N. et al. Nanoemulsions: A Review on Various Pharmaceutical Application. Global Journal of Pharmacology, v.06, p.222-225, 2012. Available from: <https://idosi.org gjp/6(3)12/10.pdf $>$. Accessed: Nov. 15, 2020. doi: 10.5829/idosi. gjp.2012.6.3.65135.

TOMAR, R. S. et al. Evaluation of anthelmintic activity of biologically synthesized silver nanoparticles against the gastrointestinal nematode, Haemonchus contortus. Journal of Helminthology, v.91, p.454-461, 2017. Available from: <https:// pubmed.ncbi.nlm.nih.gov/27374616/>. Accessed: Jan. 08, 2021. doi: 10.1017/S0022149X16000444

TRONCARELLI, M. Z. et al. Safety of a nanopropolis formulation intended for intramammary treatment of bovine mastitis in organic dairy herds. Revista Brasileira de Higiene e Sanidade Animal, v.08, p.520-527, 2014. Available from: <http://hdl.handle. net/11449/140874>. Accessed: Dec. 20, 2020.

UNDERWOOD, C. et al. Nanomedicine and veterinary science: The reality and the practicality. Veterinary Journal, v.193, p.12-23, 2012. Available from: <https://pubmed.ncbi.nlm.nih gov/22365842/>. Accessed: Nov. 15, 2020. doi: 10.1016/j. tvj1.2012.01.002.

VALENTE, J. S. S. et al. In Vitro Activity of Melaleuca alternifolia (Tea Tree) in Its Free Oil and Nanoemulsion Formulations Against Pythium insidiosum. Mycopathologia, v.181, p.865-869, 2016. Available from: <https://pubmed.ncbi.nlm.nih.gov/27544535/> Accessed: Jan. 21, 2021. doi: 10.1007/s11046-016-0051-2.

VALENTE, J. S. S. et al. In vitro anti-Pythium insidiosum activity of biogenic silver nanoparticles. Medical Mycology, v. 57 , p.858-863, 2019. Available from: <https://pubmed.ncbi.nlm.nih. gov/30597067/>. Accessed: Jan. 21, 2021. doi: 10.1093/mmy/ myy 147 .

VALENTE, J. S. S. et al. Biogenic silver nanoparticles in the treatment of experimental pythiosis Bio-AgNP in pythiosis therapy. Medical Mycology, v.58, p.913-918, 2020. Available from: <https://pubmed.ncbi.nlm.nih.gov/32030424/>. Accessed: Jan. 21, 2021. doi: 10.1093/mmy/myz141.

VANDAMME, T. F. et al. Low-energy nanoemulsification to design veterinary controlled drug delivery devices. International Journal of Nanomedicine, v.05, p.867-873, 2010. Available from: $<$ https://pubmed.ncbi.nlm.nih.gov/21042549/>. Accessed: Nov. 15, 2020. doi: 10.2147/IJN.S13273.

VICENSOTTI, J. M. et al. Competitividade brasileira no comércio exterior da carne bovina. Revista IPecege, v.05, p.0718, 2019. Available from: < https://revista.ipecege.org.br/Revista/ article/view/372>. Accessed: Nov. 15, 2020. doi: 10.22167/r. ipecege.2019.5.7.

VIDIC, J. et al. Advanced biosensors for detection of pathogens related to livestock and poultry. Veterinary Research, v.48, p.01-22, 2017.Available from: <https://pubmed.ncbi.nlm.nih.gov/28222780/>. Accessed: Nov. 15, 2020. doi: 10.1186/s13567-017-0418-5.

VON SAMSON-HIMMELSTJERNA, G. et al. Will technology provide solutions for drug resistance in veterinary helminths? Veterinary Parasitology. v.132, p.223-239, 2005. Available from: $<$ https://pubmed.ncbi.nlm.nih.gov/16118040/>. Accessed: Nov. 15, 2020. doi: 10.1016/j.vetpar.2005.07.014.

WEIR, A. et al. Titanium dioxide nanoparticles in food and personal care products. Environmental Science \& Technology, v.46, p.2242-2250, 2012. Available from: <https://pubmed.ncbi. nlm.nih.gov/22260395/>. Accessed: Dec. 20, 2020. doi: 10.1021/ es204168d.

WELLS, P. G, et al. Oxidative stress in developmental origins of disease: teratogenesis, neurodevelopmental deficits, and cancer. Toxicological Sciences, v.108, p.4-18, 2009. Available from: $<$ https://academic.oup.com/toxsci/article/108/1/4/1673173>. Accessed: May, 05, 2021. doi: 10.1093/toxsci/kfn263.

YUAN, P. et al. Multicolor quantum dot-encoded microspheres for the fluoroimmunoassays of chicken newcastle disease and goat poxvírus. Journal of Nanoscience and Nanotechnology, v.09, p.3092-3098, 2009. Available from: $<$ https://pubmed.ncbi.nlm.nih.gov/19452974/>. Accessed: Dec. 09, 2020. doi: 10.1166/jnn.2009.009.

ZHAO, $\mathrm{K}$. et al. IgA response and protection following nasal vaccination of chickens with newcastle disease virus DNA vaccine nanoencapsulated with Ag@SiO2 hollow nanoparticles. Scientific Reports, v.12, 25720, 2016. Available from: <https://www.nature. com/articles/srep25720>. Accessed: Dec. 20, 2020. doi: 10.1038/ srep25720.

ZHAO, K. et al. Enhancing Mucosal Immune Response of Newcastle Disease Virus DNA Vaccine Using N-2-Hydroxypropyl Trimethylammonium Chloride Chitosan and N,O-Carboxymethyl Chitosan Nanoparticles as Delivery Carrier. Molecular Pharmaceutics, v.15, p.226-237, 2018. Available from: <https:// pubmed.ncbi.nlm.nih.gov/29172532/>. Accessed: Dec. 20, 2020. doi: 10.1021/acs.molpharmaceut.7b00826. 